\title{
Pozitivizmus és hermeneutika Vilfredo Pareto társadalomelméleti gondolkodásában
}

\author{
Csernus Éva \\ https://doi.org/10.51624/SzocSzemle.2018.3.3 \\ Beérkezés: 2018. 05. 17. \\ Átdolgozott változat beérkezése: 2018. 08. 27. \\ Elfogadás: 2018. 10. 31.
}

\begin{abstract}
Összefoglaló: Miben áll az egyén társadalomformáló szerepe? Miben gyökerezik önállósága? Ha a társadalmi cselekvést a szubjektív, irracionális aspektusok által dominált fogalomnak tekintjük, miként valósítható meg a pozitivista episztemológiára és módszertanra alapozott vizsgálata? E fő kérdések vizsgálata képezi az olasz teoretikus, Vilfredo Pareto szociológiaelméletének pozitivista és hermeneutikai aspektusait taglaló tanulmányom gerincét, melyet olvasva az egykoron klasszikusként kanonizált, majd - különböző okokból - elfeledett szerző társadalmi gondolataiba nyerhetünk bepillantást.
\end{abstract}

Kulcsszavak: irracionalitás, hermeneutika, pozitivizmus, cselekvéselmélet

\section{Bevezetés}

Alan Sica, amerikai szociológus a Weber, Irrationality, and Social Order (1988) címú munkájában arra tesz kísérletet, hogy - a weberi „értékracionalitás” fogalmának újszerú értelmezése által - új nézőponttal szolgáljon a racionalitás-irracionalitás problematikáról szóló szociológiai diskurzus számára. Célja eléréséhez - a Parsons által még klasszikusként kanonizált - Vilfredo Pareto társadalomfelfogását hívja összehasonlító módon segítségül. Meggyőződése szerint a struktúrákat hangsúlyozó szociológiai gondolkodásnak újra fel kell fedeznie az egyéni irracionális tényezőket, végső soron pedig a társadalom alapegységét: az egyént. Vajon nem idejétmúlt ezt a kérdést a 19-20. század fordulójának társadalomteoretikusaihoz intézni? Sica problémafelvetése arról tanúskodik, hogy a társadalmi racionalitás-irracionalitás kérdésköréről való gondolkodás - akár klasszikusok megkérdezése révén is - napjainkig magában hordozza annak lehetőségét, hogy a társadalomról alkotott képünk újabb szemponttal, felismeréssel - vagy esetleg újabb lényeges kérdéssel - gazdagodjon.

Tanulmányom bevezetéseként hadd idézzem fel röviden Pareto társadalomelméletének alapvető célkitűzését: racionális megfontolásokra alapozva megragadni a társadalmi cselekvéseket uraló irracionalitást, s tenni ezt főként azért, hogy a modern demokratikus politikai ${ }^{1}$ és társadalmi berendezkedésekről és mechanizmusokról objektív(ebb) képet alkothassunk. Maga a célkitǔzés magában rejti a kérdést: lehetséges-e egyáltalán szigorúan tapasztalati eszközökkel vizsgálni a társadalmat, amennyiben elfogadjuk azt

1 Pareto politikafelfogása jelen írásban csupán említésként jelenik meg, a továbbiakban nem képezi a vizsgálat tárgyát. 
a kiinduló feltevést, miszerint a társadalmi valóságban az individuumok alapvetôen irracionálisak? Véghezvihető-e a társadalom individuális, sőt szubjektív aspektusainak pozitivista episztemológiára és módszertanra alapozott vizsgálata? Esetleg Pareto vizsgálatai olyan eredményeket hoznak, melyek túlmutatnak saját előre meghatározott elméleti keretein, s már egy új módszertan alkalmazását igénylik?

Az alábbi tanulmány a Pareto társadalomelméletében meglévő pozitivista és hermeneutikai vonások, illetve e két megközelítési mód keveredésére utaló jegyek vizsgálatára irányul. A hangsúlyt az individualitás, a szubjektivitás és az irracionalitás - egymással összekapcsolódó - fogalmaira helyezem, mivel ezek napjainkig a társadalmi gondolkodás meghatározó problémái közé tartoznak.

Pareto társadalomtanát a legtöbb értelmező mint pozitivista, azon belül esetleg egyfajta mechanikus szemléletű vagy pszichologikus, illetve ezek kombinációjaként leírható elméletként kezelte és kezeli napjainkban is. ${ }^{2} \mathrm{Az}$ utóbbi években azonban Maurizio Bach (2004) és Gert Albert (2004) révén - megjelent a paretói elmélet olyan megközelítési módja is, amely a pozitivista vonások mellett kimutatja a hermeneutika irányába mutató gondolatokat. E két szerző munkája saját elemzésem kiinduló- és viszonyítási pontjául szolgál, az általuk elért eredményekre támaszkodva törekszem a kérdés további árnyalására. Maurizio Bach elemzése a reziduumok újszerú értelmezése által nyitja meg az utat a paretói teória hermeneutikai elméletként való interpretálása felé, Gert Albert viszont a pozitivista vonások elemzése során lel rá arra a gondolati összetevőre, amely nem illeszthető bele az egyébként egységesnek tűnő paretói - pozitivista - koncepcióba, és amely világosan a hermeneutika megjelenésére utal.

Pareto aktorának társadalomformáló erejét nem lehet a racionális mérlegelésen alapuló döntési képességében keresni, mivel ez szerinte csupán igen korlátozott mértékben jellemző rá, azonban ennek ellentéte, vagyis a tökéletes ösztönvezéreltség feltételezése is egyoldalú értelmezésnek bizonyul. Amennyiben elemzésünk igazolja ezt a feltevést, magától adódik a kérdés: ha egyik véglet sem, akkor vajon mi jellemzi a paretói egyént? Írásom célja tehát, hogy a paretói individuum fogalmának vizsgálata által lehetővé váljon társadalomalakító szerepének új, pontosabb értelmezése is.

\section{Pareto, a társadalmi gondolkodó}

Vilfredo Pareto (1848-1923) neve elsősorban a közgazdaságtan körébe tartozó megfontolásai révén vált ismertté, társadalomelméleti gondolatai jóval kevesebb figyelmet kaptak. Jogosan merülhet fel a kérdés, hogy érdemes-e leporolni egy éppen száz évvel ezelőtti - nagyrészt elfeledett - elméletet? Tud-e esetleg új és termékeny nézőponttal szolgálni számunkra a társadalmi jelenségek vizsgálatában? Mint látni fogjuk, a Pareto társadalomelméletében kifejtett ismeretelméleti és módszertani alapvetések áttekintése szemléletes példát kínálhat arra, hogy egy bizonyos szempontból újszerü-

2 Lásd például: Bongiorno (1930); Henderson (1935); Sorokin (1928); Schumpeter (1949); Stark (1963); Aron (1989); Busino (2002). 
nek - sőt a maga korában merésznek - számító felvetés miként ütközik a saját maga által kijelölt módszertani keretekbe. Ebben az értelemben a paretói elmélet mint egy paradigmaváltásról készült pillanatfelvétel tárul fel előttünk. Dolgozatunk ennyiben is túlmutat egy elmélet egyszerú rekonstrukcióján és a puszta tudománytörténeten, és úgyszólván a múködésben lévő elméleti gondolkodásba engedhet betekintést.

Pareto teoretikusi pályájának első éveit jellemzően közgazdaságtani kérdések vizsgálatának szentelte, s csak ezt követően - a 19. század végén - fordult érdeklődése a tágabban vett társadalmi jelenségek felé. Talcott Parsons - mások mellett - Pareto társadalomfelfogását bemutató klasszikus munkájában (1949) hangsúlyozza: azok a gondolatok (például az érzelmi, ösztönös motivációk) fordították figyelmét a szociológiai elméletek felé, melyek irrelevánsnak bizonyultak egy - alapvetően utilitarista felfogást képviselő - közgazdasági elmélet számára. Mindazonáltal Pareto közgazdaságtani és szociológiai felfogásában felfedezhető valamiféle kontinuitás: számára ugyanis - hasonlatosan közgazdaságtani koncepciójához - a társadalom alapegységét jelentő egyén elsősorban nem más, mint homo agens, azaz cselekvő ember. A társadalmi folyamatok megismerésének középpontjába tehát a cselekvés fogalmát állítja, egy új perspektívát jelölve ki, melynek kulcskérdését az egyéni cselekvések motivációi jelentik. Közgazdaságtani gondolataiból kiindulva logikusan feltételezhető lenne, hogy társadalmi aktorát is a racionalitás jellemzi, azonban szociológiaelméletében az egyén a homo oeconomicusszal ellentétben alapvetően „nem logikus”, azaz cselekedetei érzelmi és ösztönös indíttatásúak.

\section{A pozitivista Pareto - Kísérlet a „valódi” pozitivista elmélet megalkotására?}

Leszek Kolakowski (1968) a pozitivista gondolkodás történetét tárgyaló munkájában egyrészt e gondolkodási mód különféle alakjait tárgyalja, másrészt azokat az alapelveket azonosítja, melyek e sokszínűség közepette is - egyfajta közös nevezőként - közös jelleget kölcsönöznek az idetartozó sokféle elmélet számára. Tömören összegezve ezek az elvek a következők: 1. a fenomenalizmus elve, melynek értelmében nem tesznek különbséget a „jelenség” és a „lényeg” között; 2. a nominalizmus elve, mely szerint az általános fogalmak kizárólag konkrét dolgokra utalnak, nem valami szubsztantív létezőkre; e két elvből következik az értékítéletektől való tartózkodás elve; s végül: 3. a tudományos metodológia egységének a tételezése. Ezekre a Kolakowski által beazonosított elvekre támaszkodom a paretói elmélet elemzésében.

Pareto a társadalom felépítésére és működésére vonatkozó felfogását az 1916-ban megjelent, Trattato di Sociologia Generale címú monumentális munkájában foglalta össze. Ebben a korszakban a társadalom kérdéseivel foglalkozó gondolkodók számára - mint ismeretes - még a szociológia mint tudomány önállóságának elismertetése, ezzel összefüggésben pedig tárgyának és módszerének meghatározása jelentette a központi kérdést. Ebből a sajátosságból eredően a Trattato bevezető fejezete a szociológia 
mint tudomány definiálását követően olyan elméleti és módszertani megfontolások tisztázását tartalmazza, melyek a korszak elméleti vitáinak kereszttüzében álltak. Pareto célja egy olyan koherens módszertani megfontolásokon nyugvó társadalommagyarázat kidolgozása volt, amely konzekvensen a tapasztalati úton megragadható társadalmi tények megfigyelésén, és az ezekből kirajzolódó törvényszerűségek megállapításán alapul. Elméletének kereteit jól láthatóan a korszak egyik meghatározó tudományos programja, a pozitivizmus talaján dolgozza ki. ${ }^{3}$ Ennek jegyében elutasít mindennemü a priori ismeretet mint eleve adott igazságot. ${ }^{4}$ Pareto felfogása szerint tehát a társadalmi valóság megismerésének tények megfigyelésén kell nyugodnia, $s$ ehhez a szociológiai vizsgálódások során más - elsősorban természettudományos területeken sikerrel alkalmazott módszerek, módszertani elvek szolgálhatnak mintául. A deklarált alapvetésen túl vegyük most sorra pozitivizmusának - általa részletesebben taglalt - fö gondolati elemeit.

Elsőként vizsgáljuk meg, miként határozta meg saját felfogását más gondolkodókéhoz képest. Elődei - Auguste Comte és Herbert Spencer, akiknek a programjai kétségtelenül saját pozitivizmusának gyökereit jelentették - elméleti megfontolásait visszatérően éles kritikával illeti. Érvelése szerint Comte és Spencer megközelítési módját éppúgy dogmatikus logika jellemezte, mint minden metafizikai gondolkodást. Ezzel Pareto voltaképpen azt veti a szemükre, hogy a mégoly jelentős elődöknek comte-i terminológiával élve - sem sikerült a „metafizikai stádiumból” a „pozitív stádiumba” lépniük. Miként kifejti: ezek az elméletek dogmatikusak abban az értelemben, hogy egyfajta sajátos hitet fejeznek ki, hasonlatosan a vallásokhoz, melyek kizáró logikát alkalmaznak, vagyis ha valaki az egyik által képviselt igazságot vallja, akkor az eleve kizárja a másik igazságait. ${ }^{5}$ Pareto szerint ez az „eleve kizárás” jelenti a kulcsproblémát, s emiatt nevezi az említett két szerző által képviselt felfogást dogmatikus pozitivizmusnak. Szerinte mind Comte, mind Spencer felfogásában a pozitivizmus mint eszme került a középpontba, s a valóságot e „szemüvegen keresztül” nézték. Ennek következtében azonban - eredeti célkitǔzéseik ellenére - nem kerültek közelebb a tapasztalati tényeken alapuló társadalomelmélet megalkotásához, vagyis a valóság megragadásához. „Az idő előrehaladtával A. Comte prófétává vált, a gondolatok harca véget ért, s ő annak egyértelmú győzteseként jelenik meg; a tan ex cathedra kimondatott, s így természetes módon csupán az érzelmek maradnak, az ő érzelmei” (Pareto 1923: 161, I. kötet). Pareto ezzel szemben olyan álláspontra törekszik, amely nem kérdőjelezi meg más nézőpontok létjogosultságát: „Nem tartjuk haszontalannak azokat a szociológiai megközelítéseket, melyek dogmatikus elvekből indulnak ki, (...) csupán

3 Utalni érdemes itt arra a nem elhanyagolható körülményre, hogy Pareto eredeti képzettségét tekintve építőmérnök volt, így ebből is fakadhatott a pozitivizmus iránti fogékonysága.

4 Durkheim (1978) A szociológia módszertani szabályai címú munkájában ehhez igen hasonló tudományos módszertani elveket fejt ki 1895-ben.

5 Paretóhoz hasonlóan Émile Durkheim is kritikával illeti e két szerző felfogását, mégpedig arra hivatkozva, hogy elméletüket nem a valóságot jelentó dolgok vizsgálatára, hanem az azokról alkotott sajátos eszméikre alapozzák. Ld. Durkheim (1978: 41-43). 
azt várjuk el tőlük, hogy érvelésük és kiindulópontjuk, amennyire csak lehetséges, világos [chiaro] és szigorúan következetes [rigoroso] legyen" (Pareto 1923: 4, I. kötet).

Mindezekből következik Pareto tudományos elméletekre vonatkozó osztályozási struktúrája, melyben az objektivitás és a szubjektivitás - mint lehetséges szemléletmódok - jelentik a fő differenciáló tényezőt. Meggyőződése szerint világossá kell tenni az elmélet alkotójának és művének - magának az elméletnek - a viszonyát, ami azt jelenti, hogy csak azokat az elméleteket lehet objektívnek tekinteni, melyek az alkotótól és a befogadó személyétől függetlenül értelmezhetőek. Alosztályokat a vizsgálat tárgyának tapasztalati úton való megragadhatósága, ill. megragadhatatlansága szerint alkot, ezen belül további alosztályokat a vizsgált jelenségek közötti logikai kapcsolatok alapján. E rendszeren belül Pareto saját elméletét az objektív aspektust képviselő, tapasztalati tényeket vizsgáló, logikai kapcsolatokon alapuló elméletek közé sorolja. Ebből következik, hogy kizárólag olyan fogalmakat és elveket alkalmazhat, amelyek a tapasztalásból származnak. Ezzel pedig gondolkodásának is szigorú határokat szab: saját vizsgálódásaiból kizárja azokat a kérdéseket, melyek tények értékelésére vonatkoznak, az értékítéleteket ugyanis alapvetően a metafizika, a filozófia hatáskörébe utalja. Pareto álláspontja szerint minden olyan kérdésfeltevés, amely a dolgok „lényegére”, abszolutizálására irányul, kívül esik a logikai-tapasztalati elméletalkotás keretein.

Mindezekkel összefüggésben merül fel a nyelvi kifejezések pontatlanságának problematikája. Egy olyan elmélet számára, mely a valóság megfigyelésére és lehető legpontosabb leírására törekszik, megkerülhetetlen kérdés, hogy állításainak leírása során milyen terminológiai készlet áll rendelkezésre annak érdekében, hogy a matematikában vagy más természettudományokban elért egzaktságot és érthetőséget akár csak megközelítse. Ha a természettudományok mintáját tartjuk szem előtt ahol adott állítás alapvetően mindenki számára megközelítőleg ugyanazon jelentéstartalommal bír -, jogosnak tünik a szerző felvetése, hogy a szociológia is törekedjék kialakítani egy olyan terminológiát, amely az emberi nyelv sajátosságából fakadó félreérthetőséget a lehető legteljesebb mértékben kiküszöböli. A társadalomtudományi terminológia kidolgozására az egyetlen és leginkább alkalmas módszernek a dolgok megfigyelését tartja, elméleti viták lefolytatása helyett: „(...) először figyeljük meg a dolgot, s csak utána keressünk nevet számára” (Pareto 1923: 53, I. kötet). Ebben a folyamatban - azaz a megfigyelt dolgokra vonatkozó társadalomtudományi terminus technicusok kidolgozásában - támpontot nyújthatnak a természettudományos analógiák. Pareto példaként említi a „társadalmi egyensúly” meghatározását, melyet a fizika egyensúlyfogalmára alapozott. Ugyanakkor fontos megkülönböztetést is tesz a kettő között, hangsúlyozva, hogy a kettő csupán hasonló, egymásnak megfeleltethető, de egymással nem azonos. ${ }^{6}$

6 A nyelvi problematikára a hermeneutikai megfontolások tárgyalása során még visszatérek. 
Pareto világos célkitűzések által vezérelve rögzíti elméletének alapjait: a korábbi pozitivista elméletek hibáiból tanulva, az azokból fakadó tanulságokra alapozva olyan szigorú kereteket, határokat kíván szabni gondolkodásának, melyeken belül nem marad kérdéses az elmélet tapasztalati megalapozottsága. Legfőbb törekvését így fogalmazza meg: „A cél kizárólag tudományos: vagyis megismerni, tudni, és ennyi” (Pareto 1923: 37, I. kötet). Számára a legfontosabb lépés ebben a folyamatban nem más, mint a filozófiai „spekulációk” kizárása, összhangban Durkheim gondolatával, miszerint nem az eszméket, fogalmakat kell a szociológiai vizsgálódások tárgyává tenni, hanem magát a „dolgot”, pontosabban a tapasztalati tényekre mint „dolgokra” kell tekintenünk. Nem a dolgok lényegét kutatja, hanem a társadalmi valóságban tapasztalható uniformitások - melyek a társadalom múködésének törvényeiként foghatók fel - feltárására törekszik. David Beetham (2013) Pareto és Weber koncepcióját összehasonlító elemzésében éppen az értékek maradéktalan kirekesztésében látja a paretói gondolkodás „megrekedésének” okát, ezáltal ugyanis csupán implicit módon bukkan fel gondolkodásában az értékek társadalmi cselekvésben játszott szerepének felismerése, amely körülményre vele ellentétben Weber tudatosan reflektál.

$\mathrm{Az}$ eddigiekben bemutatott elméleti alapvetések mintha egy empirista neopozitivista episztemológia irányába mutatnának, éppen a nyelv jelentőségének felismerése által.

Elemzésünk eddig a pontig a paretói koncepció jellegét meghatározó pozitivista vonásokat az elméleti keretek vonatkozásában tárgyalta, az viszont nyitott kérdés maradt, hogy cselekvésfogalma milyen jegyeket mutat. E kérdés tárgyalásához járul hozzá Gert Albert felvetése, amely szerint kimutatható egyfajta strukturális azonosság Pareto elméletekre és cselekvésekre vonatkozó osztályozása között. Ezzel arra utal, hogy a paretói teória nem csupán formai, de tartalmi tekintetben is magán viseli a pozitivista filozófia hatását. Mindazonáltal elemzése során - melyet többek között Williamsnek (1981) az externális és az internális okok ${ }^{7}$ közti megkülönböztetésére alapoz - világossá válik az is, hogy a paretói cselekvésfogalom az egyéni gondolkodás belső motivációit olyan - a cselekvés racionalitására nézve is - szerves módon veszi számításba, amelyben már a hermeneutikai szemlélet is egyértelműen tetten érhető.

Maurizio Bach (2004) amellett érvel, hogy ha a paretói felfogást megpróbáljuk elhelyezni a hagyományos szociológiaelméletek sorában, akkor a legszerencsésebb a posztpozitivista jelzővel illetni. E gondolat hátterében az a megfontolás áll, miszerint a paretói teória az explicit metodológiai elvei ellenére több ponton egy hermeneutikai megközelítésmód irányába mutat.

A továbbiakban tehát részletesen meg kell vizsgálnunk Pareto gondolkodásának mindazon pontjait, amelyek túlmutatnak az eddigiekben vázolt szigorúan pozitivista gondolati rendszeren.

7 Internális okok közé a cselekvések személyes motivációi sorolhatók, ezzel szemben az externális okok a cselekvő személyétől függetlenek. 


\section{Pareto elméletének hermeneutikai aspektusai}

A részletes vizsgálatot megelőzően szükségesnek látszik rögzíteni, hogy milyen ismérvek szerint történik majd a hermeneutikai jegyek azonosítása, vagyis milyen hermeneutikafelfogáson alapulnak a megállapításaim. A szociológiai gondolkodásban a hermeneutikai megfontolások mindenekelőtt három nagy - egymással is összefüggő - dilemmában látszanak kicsúcsosodni: a módszertani individualizmushoz, a mikro-makro problémához, valamint a (cselekvés)racionalitáshoz kapcsolódó kérdésekben, vitákban. Ebből (is) következik, hogy a paretói felfogás vizsgálata során ezeket a dilemmákat érintjük. Mindezzel azonban csupán a kutatás „területét” jelöltük ki, viszont maga a zsinórmérték még definiálásra vár: mi alapján tekint(het)jük hermeneutikainak Pareto elméletét? Milyen hermeneutikafogalmat használunk? Egy taxatív meghatározáshoz képest célravezetőbbnek tűnik a gondolkodás logikájának ismertetése Pareto elmélete kapcsán ugyanis éppen az jelenti a nehézséget, hogy a hermeneutikai jegyek rejtett, sokszor inkább csak implicit formában bukkannak fel. Amikor tehát hermeneutikai megfontolásokra utaló jegyeket kutatunk, mindenekelőtt olyan gondolatokat keresünk, melyekben egyrészt a társadalmi aktorok szubjektív szempontjai döntő súllyal esnek latba, másrészt cselekvésükben nem mechanikusan, ösztönösen merőben reagálva - vesznek részt, hanem tetteik „szerzőiként”, cselekvéseiknek ezzel mintegy értelmet tulajdonítva.

Pareto a társadalom müködésének vizsgálatát a cselekvésnek mint társadalmi ténynek a megismerésére alapozza, vagyis egy cselekvéselméleti veretű koncepciót tár elénk, s ennyiben - miként Bach (2004) is rámutat - a metodológiai individualizmus irányába mozdul el, a saját korában bevett, hagyományos, kollektív aspektusokat hangsúlyozó pozitivista társadalommagyarázatokkal szemben. Mai nézőpontból szinte természetesnek tűnik a cselekvést határozni meg az elemzés kiindulópontjául, azonban ahogyan Némedi Dénes (2001) rávilágít: „(...) ebben az időszakban [értsd a 19. század fordulójától a 20. század közepéig] (...) a cselekvéselmélet egyáltalán nem játszotta azt a szerepet, amelyet a későbbiekben, egyáltalán nem volt magától értetődő, hogy a társadalomkutatásnak a cselekvő és cselekvésre reflektáló egyénből kell kiindulnia" (Némedi 2011: 160). Némedi továbbá arra is felhívja a figyelmet, hogy a századforduló tágan értelmezett korszakában nem mutatható ki egyértelmú tendencia a klasszikusok gondolkodásában a cselekvéselmélet irányába (Némedi 2011: 163).

Láttuk, hogy Pareto a társadalmi világot szigorúan pozitivista metodológiára alapozva akarja vizsgálni, következésképpen egy pozitivista cselekvéselmélet kidolgozására törekszik. Albert hivatkozott álláspontja szerint azonban Pareto e tekintetben „kudarcot vall", ugyanis az általa tételezett egyén cselekvésében a szubjektív motivációk döntő jelentőségúnek bizonyulnak, így a társadalmi folyamatokra is hatást gyakorolnak. Mindennek hátterében a „mikro-makro probléma” napjainkig nyitott kérdése rejlik: a társadalom és az egyén közül logikailag melyik az elsődleges? Az összefüggésünkben még pontosabban: van-e szubjektív önállósága az egyénnek a társadalom egészéhez képest? Ennek a kérdésnek a szemléltetését szolgálhatja - még ha némileg leegyszerü- 
sítőnek tűnik is - Durkheim és Pareto idevágó - az egyéni tudat és a társadalom viszonyára vonatkozó - gondolatainak rövid összevetése. Míg a durkheimi felfogás szerint az emberi tudatot az egyéni és kollektív tudat sajátos egysége alkotja, melyben az egyéni tudat háttérbe szorul, a kollektív tudati komponens pedig valamiféle társadalmi meghatározottságot képvisel, a paretói gondolkodás ezzel ellentétesnek tűnő álláspontot képvisel, amikor a cselekvések „szubjektív racionalitását” hangsúlyozza. Mindazonáltal mindkettejük gondolkodásában kitüntetett szerepet játszanak az érzelmek és ösztönök manifesztációi (ill. reprezentációi), melyek - jóllehet leginkább implicit módon - a társadalmi folyamatok alakítóiként jelennek meg.

Érdemes tehát alaposabban szemügyre venni, hogy Pareto cselekvéselméleti felfogása mennyiben sorolható a módszertani individualizmust képviselő elméletek körébe. Azonban mielőtt ezzel a kérdéssel részletesebben foglalkoznánk, vizsgáljuk meg magát a cselekvés paretói fogalmát. Pareto a cselekvésre összetett jelenségként tekint: a tett nem önmagában áll, hanem szervesen hozzátartoznak a belső motivációk, egész pontosan - paretói terminológiával - az érzelmek kifejeződései (reziduumok), továbbá a cselekvésre adott magyarázatok (derivációk). A két utóbbi komponens megkülönböztetésének alapjául az a paretói megfontolás szolgál, miszerint egyrészt minden emberi cselekvésre hatást gyakorol a „pszichikai állapot”, ezáltal tehát a társadalmi cselekvés érzelmi, ösztönös indíttatású fenoménként tűnik fel, másrészt az egyén logikus - vagy logikusnak tűnő - magyarázatokkal próbál szolgálni a cselekedetére vonatkozóan. A paretói koncepció megértésének kulcsát kétségtelenül a reziduumok jelentik, így mibenlétük pontos megragadása megkerülhetetlen feladat, különös tekintettel arra, hogy bevetté vált az érzelmekkel, ösztönökkel való egyszerű - megítélésünk szerint leegyszerűsítő, félreértő - azonosításuk. ${ }^{8}$ A redukcionista értelmezés alapja az lehet, hogy Pareto valóban a pszichikai állapotban gyökerezteti a cselekvéseket, ráadásul ő maga sem következetes a kifejezés használata során, azonban elemzésében hangsúlyozza, hogy a reziduumok nem azonosak magukkal az érzelmekkel. Bach (2004) felvetése, miszerint a reziduumok egyfajta „prereflexív értelmezésminták” (prä-reflexive Deutungsmuster), vagy másként megfogalmazva „preracionális értelemstruktúrák" (prä-rationale Sinnstrukturen), alighanem a paretói cselekvéselmélet e kulcsfogalmának a lényegére tapint rá.

A reziduumok mibenlétének pontosabb megragadását szolgálhatja - a javasolt bachi értelmezéssel összhangban -, ha megvizsgáljuk a sentiment fogalmának filozófiai, esztétikai hátterét, mivel e kifejezést Pareto gyakran használja a reziduumok tárgyalásakor. Alfred Baeumler megfogalmazása szerint a sentiment kifejezés arra a „(...) közvetlen tudatra vonatkozik, mellyel belső folyamatainkról rendelkezünk” (Baeumler 2002: 54). Ezt a gondolatot magának a sentiment szónak az eredeti latin (sentio, -ire) jelentéstartománya is alátámasztja: a szó ugyanis gyakran 'vél', 'gondol' értelemben volt használatos. Baeumler továbbá arra is rámutat, hogy a - vélekedés 
értelmében vett - sentiment és a megalapozott tudás szembeállításával érzékelhetővé válik a tudás megszerzésének két eltérő módja. E fogalomtörténeti jellegű filozófiaiesztétikai kitérő magyarázatot adhat arra, miért nem képes Pareto következetesen tárgyalni a reziduumok fogalmát. A Trattatóban ugyanis rendre a sentimenti ('érzelmek’) kifejezést használja, amikor a reziduumokról beszél, annak ellenére, hogy egy bekezdésben leszögezi, a kettő nem azonosítható egymással: „Szem előtt kell tartanunk, hogy a reziduumok nem moshatók össze az érzelmekkel, ösztönökkel, melyeknek megfeleltethetők. Az előbbiek ugyanis csupán az utóbbiak megnyilvánulásaiként értendők, miként a hőmérő higanyszálának emelkedése is a hőmérséklet emelkedésének megnyilvánulását jelenti" (Pareto 1923: 11, III. kötet).

Vegyük most szemügyre a társadalmi cselekvés kategorizálásának kérdését. „A logikus cselekvések, legalábbis nagy részben, gondolkodás, érvelés eredményei, míg a nem-logikus cselekvések leginkább a pszichikai állapotban gyökereznek: az érzelmekben, a tudatalattiban stb. Ezek a pszichológia hatáskörébe tartoznak" (Pareto 1923: 74, I. kötet). Említést érdemlő sajátossága ennek a definíciónak az egyértelműen pszichologizáló megfogalmazásmódja, ami ugyan tekinthető a korabeli pszichológiával való kapcsolatkeresésnek, azonban maga a paretói koncepció nem ebből fakad, érvei nem pszichológiai eredetűek. A fenti idézetben felbukkan a paretói cselekvésosztályozás két fő csoportja, nevezetesen a logikus és nem logikus cselekvések. E differenciálás alapjául a cél és az eszköz kapcsolata, valamint e kapcsolat valósághoz való viszonya szolgál. A logikus cselekvések mind szubjektív, mind pedig objektív nézőpontból logikus cél-eszköz kapcsolatot jelölnek (1. ábra). Ezzel ellentétben a nem logikus cselekvések jellemzője, hogy objektív vagy szubjektív aspektusból nem tekinthetők logikusnak. A paretói gondolatmenet szerint minden szempontból logikusnak föként a gazdasági cselekvések tekinthetők, míg a nem-logikus cselekvések zöme a társadalmi/szociológiai jelenségkörbe tartozik. A korábbiakban már utaltam rá, hogy Pareto cselekvéselméletében megfigyelhető egy sajátos „szubjektív racionalitás” tételezése. „Szubjektív racionalitáson” azt értem, hogy Pareto tipizációja alapján a nem-logikus cél-eszköz kapcsolatok és végső soron a nem- logikus cselekvések is lehetnek az egyén szempontjából „racionálisak/ logikusak”. A nem-logikus cselekvések - az első típus (nem, nem) kivételével - sokkal inkább a két aspektus sajátos „diszharmóniájával” jellemezhetők. Ezt az értelmezést látszik alátámasztani maga a szerző is, amikor hangsúlyozza, hogy a nem-logikus nem azonos az illogikus cselekvéssel (Pareto 1923: 65, I. kötet).

A paretói cselekvésosztályozás alapjául szolgáló finalitáskritérium ismét csak a hermeneutikai szemléletmód irányába történő elmozdulásra utalhat. Ehhez kapcsolódva idézném Wright (1987) vonatkozó gondolatait: „A két hagyománynak [értsd a leíró és elméleti - illetve végső soron a pozitivista és hermeneutikai - tudományok alapját képező tudományos vizsgálódások hagyománya] a tudományos magyarázatok értelmezésével kapcsolatos ellentétét az oksági és teleologikus magyarázatok szembeállításával szokták jellemezni. Az első típusba tartozó magyarázatokat mechanisztikus, a második típusba tartozókat pedig finalisztikus magyarázatoknak is hívják" (Wright 1987: 44). Fontos 
ugyanakkor hangsúlyozni, hogy a paretói teóriában a teleologikus magyarázatok irányába történő elmozdulás kizárólag a cselekvésfogalom finalitáson alapuló definiálásában merül ki, a „megértés” szándéka pedig szinte tökéletesen hiányzik gondolkodásából.

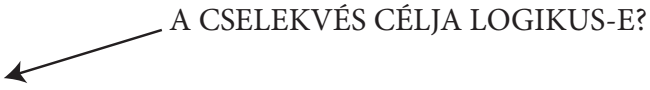

Objektív szempontból

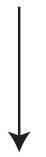

Igen

\begin{tabular}{lll}
\hline & & $\begin{array}{c}\text { 2. osztály: Nem-logikus cselekvések } \\
\text { Az objektív cél eltér a szubjektívtől. }\end{array}$ \\
1. típus: & $\mathrm{Nem}$ & Nem \\
2. típus: & $\mathrm{Nem}$ & Igen \\
3. típus: & Igen & Nem \\
4. típus: & Igen & Igen \\
\hline
\end{tabular}

$3 \alpha, 4 a$

$3 \beta, 4 \beta$
A 3. és a 4. típus fajtái

Az alany elfogadná az objektív célt, ha ismerné.

1. osztály: Logikus cselekvések Az objektív és a szubjektív cél egybeesik.

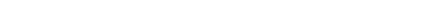

Az alany visszautasítaná az objektív célt, ha ismerné.

Forrás: PARETO: 1916, 151

A paretói cselekvésfogalom ismeretében érdemes visszatérnünk ahhoz a kérdéshez, hogy Pareto teóriája mennyiben illeszkedik a módszertani individualista elméletek körébe. Orthmayr Imre idevágó tanulmányában a következőt olvashatjuk: „A módszertani individualisták szerint (...) a kollektív fogalmakkal jelölt makroszociológiai összefüggések csak az emberi cselekvésre visszavezetve érthetők meg" (Orthmayr 1997: 3). E definícióból kiindulva a fenti kérdés könnyedén megválaszolhatónak tűnik, de valójában - miként Orthmayr is megállapítja - a két versengő szociológiai megközelítés érvrendszereit alaposabban szemügyre véve egy igen összetett gondolati háttér bontakozik ki előttünk, melyben a két álláspont közötti vita legmélyén a rész és egész viszony problematikáját találjuk. Az egyik oldalról szóló érv szerint: „(...) az egyes egyének valóban léteznek, ezzel szemben a kollektív fogalmak puszta absztrakciók" (Orthmayr 1997: 16). A kollektivista álláspont képviselői - ezzel ellentétben rendre az egyén társas voltát mint eleve létező adottságot hangsúlyozzák, s ily módon a társadalmat is eleve adott létezőként tételezik. Mind a kiinduló definíció, mind pe- 
dig a társadalom absztrakt értelmezése alapján Pareto beilleszthető a módszertani individualizmus szellemi vonulatába, minthogy a társadalmat absztrakcióként, az emberi cselekvéseket pedig valóságos létezőként kezeli, és szociológiai fejtegetései, elemzései éppen ezért irányulnak a cselekvésekre. Gondolatmenetében tehát a társadalmi élet, a társadalmi formák az emberi cselekvések által ismerhetők meg. A Trattatóban külön fejezetet szentel annak, hogy a különféle társadalmi intézmények - mint a jog, az erkölcs vagy a vallás - esetében rámutasson arra a fentebb már említett tényre, hogy ezen intézmények mindegyike az egyéni cselekvésekben, s végső soron az egyén természetes hajlamaiban gyökerezik. E ponton azonban - az emberi cselekvésekre ható természetes hajlamok hangsúlyozásával - érezhetően problematikussá válik a paretói felfogás módszertani minősítése, melyet az Orthmayr által felajánlott további - a cselekvésben rejlő döntést hangsúlyozó - definíció csak még tovább árnyal azáltal, hogy támpontot nyújt számunkra nem csupán Pareto individuumfelfogásának, de lehetséges hermeneutikai értelmezésének megragadásához is. „Miért kellene hát a döntést előnyben részesítenünk a cselekvéssel szemben? A válasz egyszerú: azért, mert a döntés biztosítja az egyéni cselekvés autonómiáját. (...) Ha ugyanis az emberi cselekvéseket a környezeti feltételek, a szocializáció vagy bizonyos pszichikai folyamatok eredményének tekintjük, akkor elveszítik önálló magyarázóerejüket, s pusztán más folyamatok szükségszerű eredményeivé vagy megnyilvánulásaivá válnak. (...) A módszertani individualizmus álláspontja szerint viszont az egyének nemcsak végrehajtói, hanem szerzői is cselekedeteiknek. A „)kemény társadalmi és pszichikai tényezők nem tudtukon kívül és akaratuktól függetlenül, hanem ezek közvetítésével és ezektől megszűrve hatnak" (Orthmayr 1997: 26). E gondolatmenet alapján döntő jelentőségúvé válik, hogy Pareto individuumának cselekvésében tetten érhető-e a fent leírt döntési momentum. A paretói meghatározás szerint a logikus érvelés, mérlegelés - végső soron a döntés maga - elsősorban a különféle gazdasági és szakmai tevékenységek esetében tapasztalható, s minden más cselekvés az ember pszichikai állapotában, a tudatalattiban ('subcoscienza') gyökerezik. Mindazonáltal hangsúlyozza azt is, hogy a cselekvések valamiféle logikával felruházott cél-eszköz választáson alapulnak. Mindezek fényében felmerülhet a kérdés: a paretói individuum társadalmi cselekvéseiben valóban egyénként, tehát önálló döntéshozóként, s ezáltal társadalomformáló erőként jelenik-e meg? Egyáltalán, ha - a paretói logikát követve - azt feltételezzük, hogy a társadalmi egyén nem racionális döntéseken alapuló cselekvő, akkor ez jelenti-e azt is, hogy minden tudatosságot nélkülöz, ami annyit jelentene, hogy ösztönei által vezérelt? Pareto ebben az esetben ugyanis hiába választja kiindulópontjául a cselekvést, ha a valóságban az egyén nem rendelkezik önálló, valamiféle tudatosságot tükröző mérlegelési képességgel. Ugyanakkor a döntési motívummal kapcsolatban érdemes átgondolni, hogy mit értünk döntésen. Hagyományosan - s ez elsősorban a fogalom közgazdaságtani gyökereiből ered - a döntést racionális cél-eszköz kapcsolatként szokás érteni, azonban épp a hermeneutika talaján felvethető a szubjektivitás nézőpontja - elegendő, ha csak az ízlés eszté- 
tikai fogalmára gondolunk -, s ezáltal a döntésben a célszerú megfontolás helyébe a tudatos választás kerülhet, ráadásul a döntés esztétikai fogalma világíthat rá arra is, hogy a döntés nem tekinthető a tudatosság szinonimájának. Ezek alapján az elemzés számára elkülöníthetőnek tűnik a racionális döntésen, és ezzel szemben a tudatos választáson alapuló cselekvés, ugyanis belátható, hogy miként a racionális döntés is lehet célszerú, de nem tudatos, éppúgy a választás is lehet tudatos, de nem célszerû. Ez esetben a kérdés nem úgy fogalmazódik meg, hogy Pareto individuuma racionális mérlegelésre alapozza-e céljai elérését - minthogy tudjuk, hogy a szerző álláspontja szerint nem erről van szó -, hanem hogy a cselekvés tudatos egyéni választás eredményének tekinthető-e. Kérdésfeltevésem tehát a célszerúség és a tudatosság fogalmának szembeállításán alapul. Ugyanakkor el kell ismerni, hogy a választásra alapozott egyéni önállóság nem érvényesül a paretói koncepció egészében: például a szexualitás reziduumának esetében, amely paretói értelmezés szerint a szexualitáshoz kapcsolódó társadalmi, erkölcsi, vallási elvárások, szabályok cselekvésre gyakorolt hatásait képviseli, sokkal inkább beszélhetünk valamiféle - weberi értelemben vett - értelemtulajdonításról. Mindazonáltal már a cselekvés komponensei és az osztályozási struktúra szempontrendszere alapján is belátható, hogy a paretói individuum nem egyszerűen ösztönös cselekvő. Az egyéni pszichológiai adottságok hangsúlyozása ellenére Pareto - jóllehet implicit módon - sokkal inkább a tudati karakterek elemzését tárja elénk. Igaz tehát, hogy a társadalmi cselekvést az érzelmekben, ösztönökben gyökerezteti, azonban ezek vizsgálatát nem a szociológia, hanem a pszichológia hatáskörébe tartozónak tekinti. A törekvése ennek megfelelően arra irányul, hogy az érzelmek társadalmi hatásai - maguknak az érzelmeknek a konkrét elemzése nélkül - valamilyen módon megragadhatóvá váljanak. Ennek érdekében alkotja meg a reziduumok fogalmát: „A reziduumok nem valós létezők; csupán analitikus fogalmak, melyeket a kutató a társadalmi rendszer múködésének megértésére és leírására használ. (...) A reziduumok az objektív valóságban nem, de szubjektíven léteznek, szorosan kapcsolódva az őket megalkotó és őket élettel megtöltő egyénhez" (Busino 2002: 51). Ami a reziduumok elvi pozícióját illeti, Raymond Aron (1989) értelmezéséhez kapcsolódva azt mondhatjuk, hogy a szociológiai vizsgálódás számára elérhetetlen érzelmek és a konkrét tettek között helyezkednek el. Ezzel ismét a korábbiakban már idézett bachi megfontoláshoz érkeztünk vissza, mely szerint a reziduumok valamiféle preracionális értelemstruktúrát (prä-rationale Sinnstrukturen) jelentenek, s ebben az értelemben esetükben a cselekvések érzelmekre való reflektálási képességéről van szó. Ebben egyrészt a paretói gondolkodás logikájának kulcsmozzanata, másrészt az elméletében keveredő pozitivista és hermeneutikai vonások mutatkoznak meg. „A módszertani individualisták maguk is erőteljesen élnek a »rejtett entitásokra« hivatkozás eszközével: központi fontosságú magyarázó tényezőik - az egyéni preferenciák, vélekedések vagy szándékok - maguk sem megfigyelhetők, hanem csak megnyilvánulásaik alapján azonosíthatók. (...) Továbbmenve: a nem pusztán belső, tudati cselekvések, de a kül- 
ső, fizikai tevékenységek értelme sem közvetlenül megfigyelhető, hanem értelmezésfüggő” (Orthmayr 1997: 17).

Az értelmezésfüggőség problematikája - mint a hermeneutikai megközelítési mód egyik jellegzetes problémafelvetése - Pareto gondolkodásában a nyelvi kérdés felvetésének formájában jelenik meg. A nyelvi sajátosságból eredeztethető értelmezési problematika más-más formában jelenik meg tudománymódszertani és a cselekvés fogalmához kapcsolódó megfontolásaiban. A kérdés tudománymódszertani jelentőségét - miként a pozitivizmusáról szóló fejezetben láthattuk - ugyan felismeri, azonban az általa kínált megoldás alapvetően a pozitivista logika jegyeit viseli magán (előbb figyeljük meg a valóságot, s csak ezt követően keressünk megfelelő elnevezést számára). Megközelítését lényegében a feltárt társadalmi jelenségek értelmezésén alapuló tudományos terminológiák alkotására irányuló szándék hiánya jellemzi.

Pareto pozitivizmusának tárgyalása során felvetődött, hogy gondolkodása egyfajta empirizmus irányába való mozgásként is felfogható. Ezzel tudatosan utalni kívántam a bécsi kör neopozitivista felfogására, melynek egyik legfőbb gondolatát éppen ez jelentette. Azonban az alábbi idézettel jól illusztrálható, hogy Pareto felfogása sokkal inkább a hermeneutika, semmint a valódi empirizmus irányába mutat. A bécsi kör gondolkodói a következő megfontolásokra alapoztak: „Miután az elme valóságos múködése nem publikus, s hozzáférhetetlen az interszubjektíve ellenőrizhető megfigyelés számára, úgy vélték, az episztemológia nincs följogosítva arra, hogy homályos és világos ideákról, asszociatív kapcsolatokról, egyáltalán, mentális struktúrákról és eseményekről beszéljen. A megismerés mentális kategóriákat használó értelmezése helyett a nyelvet állították a középpontba, melyben a kognitív folyamatok testet öltenek, vizsgálhatóvá, a rájuk vonatkozó elgondolások diszkutálhatóvá és ellenőrizhetővé válnak" (Laki 1998: 8). A paretói cselekvésfelfogásban kitüntetett szerepet kap a szóbeliség azáltal, hogy a cselekvés komponenseiként megkülönbözteti a derivációkat, melyek lényegében az egyén racionalizáló hajlamát képviselik. Deriváción ugyanis a konkrét cselekvés nem logikus voltának elfedését szolgáló magyarázó momentumot érti. A derivációk a legkülönfélébb magyarázatokat jelenthetik. Pareto szerint a tudományos gondolkodás hibája sok esetben éppen abban áll, hogy ezeket a magyarázatokat vizsgálja, s nem az általuk elfedett valódi motivációkat. A nyelviség problematikája e ponton különösen világosan jelentkezik, ugyanis nem csupán arról van szó, hogy maguknak a magyarázatoknak az érthetősége válik viszonylagossá a közlő és a befogadó viszonylatában, hanem arról is, hogy a tudományos vizsgálódások is ezekre a sokszor homályos komponensekre alapoznak, és így saját elemzéseikben is a korábbiakban már tárgyalt terminológiai pontatlanság jelenik meg. A probléma forrását - miként Pareto is felismeri - az jelenti, hogy a cselekvésekről szóló tudásunk alapvetően a szóbeliségen alapul: ha meg akarjuk tudni egy másik ember cselekvésének motivációját, akkor a legegyszerúbb módnak az tűnik, ha megkérdezzük tőle. Ily módon azonban - a paretói terminológia szerint - csupán a derivációkat ismerhetjük meg, s téves következtetések levonására juthatunk. Ezen érvelés alapján a modern 
kor „racionalitáskultusza” sokkal inkább jelenti a cselekvések magyarázatával kapcsolatban tapasztalható fokozódó igényt, mintsem a valóságos racionalitás térnyerését. A derivációk csupán a cselekvés „utólagos” racionalizáló tendenciáira utalnak.

\section{Záró gondolatok - Pozitivista hermeneutika vagy hermeneutikai pozitivizmus?}

Pareto társadalomelmélete számos ponton problematikusnak tűnhet, érvelése több szempontból is megkérdőjelezhető, azonban kétségtelenül a társadalmi valóság egy olyan sajátosságáról próbált állást foglalni, amelyet napjainkig a társadalom megismerésére törekvő gondolkodók döntő kérdéseként tartunk számon: miként juthatunk közelebb az egyének alkotta társadalmi valóság megismeréséhez?

Erre a kérdésre vonatkozott a fenti tanulmány kulcskérdése is, mely a paretói individuum jellegére irányult: ha nem önálló döntéshozó, de nem is tisztán ösztönlény, akkor miben érhető tetten az önállósága? Végül arra az eredményre jutottunk, hogy Pareto homo sociologicusának önállósága a tudatos választás képességében jut érvényre. Ehhez az eredményhez három döntő jelentőségű megfontolás vezetett el: először is Albert bizonyítása az internális-externális okok paretói ötvözésére vonatkozóan, másodszor Bach - korábbiakhoz képest alternatívát jelentő - reziduumfelfogása, s végül Baumler érvelése a megalapozott tudás és a sentiment két eltérő tudásszerzési módként való értelmezése mellett.

Befejezésül vonjunk mérleget a többi kiinduló kérdést illetően is, hogy ily módon tisztább képet alkothassunk az általa tételezett társadalmi világ mibenlétéről. E célt az szolgálja legjobban, ha a két megközelítési mód (pozitivizmus és hermeneutika) megnyilvánulását külön-külön vizsgáljuk meg Pareto módszertani megfontolásaiban és cselekvésfogalmában.

Pareto tudományelméleti fejtegetéseiből kiolvasható az az implicit módon jelen lévő gondolat, miszerint az igazi tudomány valójában az, amelyik logikus-tapasztalati módszereken, vagyis szigorúan pozitivista alapokon nyugszik. Ugyan a tudományok osztályozására vonatkozó gondolatai - s egyéb megengedő kijelentései - alapján azt feltételeznénk, hogy a pozitivista ismeretelméletet csupán egy lehetséges megközelítési módnak tekinti, azonban az általa felsorakoztatott példák alapján kitűnik, hogy azokat a tudományokat, elméleteket, amelyek nem a pozitivista episztemológián alapulnak, sokkal inkább pszeudotudományokként kezeli. Vissza-visszatérően kifejti, hogy minden, a feltárt jelenségek értékelésére vonatkozó kijelentést - éppen a szubjektivitása, s végső soron viszonylagossága miatt - eredendően pszeudologikus magyarázatnak tekint. E megfontolás tükröződik elődeinek - Comte és Spencer - gondolkodására vonatkozó kritikájában is. Mindennek hátterében természetesen ott lehet annak tudása, hogy az általa tételezett irracionalitáson nyugvó társadalommagyarázat milyen veszélyeket hordozhat magában, s ezek elkerülésének kulcsát abban vélte megtalálni, hogy szigorú keretek közé szorítja saját gondolkodását. Ebből következik, 
hogy módszertanában ugyan a felvetés szintjén megjelennek hermeneutikai megfontolások, azonban explicit törekvései egyértelműen azok kizárására irányulnak.

Ezzel ellentétben cselekvésfogalmában világosan tetten érhető a hermeneutikai megközelítési mód, mely nem csupán az individualitást hangsúlyozó elemzési alapegység révén vagy a szubjektív nézőpont létjogosultságának elismeréséből fakadóan jut érvényre, hanem elsődlegesen a reziduumok fogalmával, amely úgyszólván kísérlet arra, hogy a cselekvésekben feltáruló értelmi dimenzió a tudományos kutatás számára hozzáférhetővé váljon. E törekvés mélyén ott rejlik tehát annak felismerése, hogy a társadalom müködésének megértéséhez nélkülözhetetlen valamiféle kapcsolatot találnunk a tapasztalati tények és a külső szemlélő számára elérhetetlen egyéni hajlamok és érzések világa között. Meg kell jegyeznünk, hogy nem szükséges a paretói megoldási javaslatot helyesként elfogadnunk ahhoz, hogy elismerjük a probléma feltárásában elért eredményeit. Megjegyzendő továbbá, hogy a cselekvések elemzése terén is inkább jellemzi a gondolkodását egyfajta leíró attitűd. „Elsősorban a paretói szociológia Trattatóban véghez vitt hermeneneutikai fordulata az érdekes, még ha (...) metodológiájában ez nem tükröződik is" (Bach 2004: 172).

Összegzésként megállapíthatjuk, hogy a paretói megközelítés érdeme elsősorban a témafelvetésben áll, abban, ahogyan szembeszáll kora hagyományos - racionalitást hangsúlyozó - gondolkodásmódjával. Ugyanakkor ez a merészség a módszer megválasztására, esetleg annak átalakítására már nem terjed ki. Mindezek miatt úgy vélem, hogy elmélete leginkább „hermeneutikai pozitivizmusnak” minősíthető, maguk a pozitivista elméleti keretek és a módszertan ugyanis lényegében gátjává váltak a témafelvetésben rejlő kérdések megválaszolásának és mélyebb feltárásának.

Zárásként érdemes ismét hangsúlyozni, hogy elemzésem tárgyát egy olyan koncepció képezte, mely szemléletes példaként szolgálhat számunkra egy születőben, formálódóban lévő teória „gyermekbetegségeiről”: az elmélet megalkotásához inspirációt szolgáltató kérdések természetéből fakadóan a szerző kereteket akar szabni gondolkodásának, azonban ebből következően az elmélet formálódásának egyik - ha nem a legfőbb - jellemzőjévé válik a végletes következetességgel szembeni folyamatos küzdelme, hiszen felismerései egyértelmúen feszegetik a saját maga alkotta korlátokat. A Paretóra jellemző gondolati következetességet ugyanakkor tekinthetjük a jelentős gondolkodás meghatározó jelentőségú ismérvének is. A bevezetésben feltett kérdésre tehát, hogy miért érdekes napjainkban egy (majdnem) kereken száz évvel ezelőtti elmélet, a válasz a paretói emberkép lehet. Pareto ugyanis példával szolgált arra, hogy az egyént úgy ábrázolja a társadalom alapegységeként, hogy közben érvényre jusson önállósága is.

\footnotetext{
Abstract: How and to what extent can the individual shape society? How can its autonomy be grasped? If social action is conceptualized as dominated by subjectivity, irrationality, the question arises: how can it be examined on the basis of positivist epistemology and methodology? I will examine these questions in my paper by analysing the positivist and hermeneutical aspects of the Italian theorist Vilfredo Pareto's
} 
sociological theory. This study sheds light on the thoughts of an author who was once canonized as 'classical' but later - for various reasons - became forgotten.

Keywords: irrationality, hermeneutics, positivism, action theory

\section{Irodalom}

Albert, G. (2004): Pareto's Sociological Positivism. Journal of Classical Sociology, 4(1), 59-86.

Aron, R. (1989): Le tappe del pensiero sociologico. Montesquieu, Comte, Marx, Tocqueville, Durkheim, Pareto, Weber. Milano: Mondadori.

Bach, M. (2004): Jenseits des rationalen Handelns, Zur Soziologie Vilfredo Paretos. Wiesbaden: VS Verlag.

Baeumler, A. (2002): Az irracionalitás problémája a XVIII. századi esztétikában és logikában. Az itélőerő kritikájáig. Budapest: Enciklopédia Kiadó.

Beetham, D. (2013): Mosca, Pareto and Weber: A historical comparison. In Mommsen, W. J. - Osterhammel, J. (eds.): Max Weber and his Contemporaries. Routledge,

Bongiorno, A. (1930): A study of Pareto's treatise on general sociology. American Journal of Sociology, 36(3), 349-370.

Busino, G. (2002): Introduzione alla lettura dell'opera di Vilfredo Pareto. In Manca, G. (ed.): Vilfredo Pareto (1848-1923). L'Uomo e scienzato. Milano: Libri Scheiwiller, 19-68.

Durkheim, É. (1978): A társadalmi tények magyarázatához. Budapest: Közgazdasági és Jogi Könyvkiadó.

Henderson, J. L. (1935): Pareto's General Sociology. A physiologist's interpretation. Cambridge: Harvard University Press.

Kolakowski, L. (1968): The Alienation of Reason. New York: Doubleday \& Company.

Laki J. (1998): Tudományfilozófia. Budapest: Osiris Kiadó.

Lopreato, J. (1980): Pareto's sociology in a sociobiological key. Revue européenne des sciences sociales, 18(51), 133-162.

Moore, H. E. - Moore, B. M. (1935): Folk Implications in Pareto's. Sociology, Social Forces, 14 (2), 293-300.

Némedi D. (2011): Szociológiai és társadalomelméleti tanulmányok. Budapest: ELTE Eötvös Kiadó.

Orthmayr I. (1997): Módszertani individualizmus. Szociológiai Szemle, 3, 3-31

Pareto, V. (1935): The Mind and Society. 1-4. New York: Harcourt, Brace and Company.

Pareto, V. (1923): Trattato di sociologia generale. I-III. Firenze: G. Barbèra.

Parsons, T. (1949): The Structure of Social Action. Glencoe, Illinois: The Free Press.

Schumpeter, J. A. (1949): Vilfredo Pareto (1848-1923). The Quarterly Journal of Economics, 63(2), 147-173.

Sica, A. (1988): Weber, Irrationality, and Social Order. Berkley-Los Angeles: University of California Press. 
Sorokin, P. (1928): Contemporary Socialogical Theories. New York-London: Harper \& Brothers.

Stark, W. (1963): In search of the true Pareto. The British Journal of Sociology, 14(2), 103-112.

Weber, M. (1987): Gazdaság és társadalom. A megértő szociológia alapvonalai I. Budapest: Közgazdasági és Jogi Könyvkiadó.

Williams, B. (1981): Internal and External Reasons. In uő: Moral Luck. Cambridge: Cambridge University Press, 101-113.

Wright, G. H von (1987): Magyarázat és megértés. In Bertalan L. (szerk.): Magyarázat, megértés és előrejelzés. Budapest: Tömegkommunikációs Kutatóközpont. 